\title{
Case-control study of risk factors for human infection with influenza A(H7N9) virus in Jiangsu Province, China, 2013
}

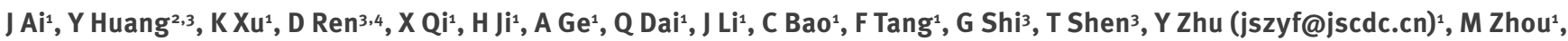
H Wang ${ }^{1}$

1. Jiangsu Provincial Center for Disease Control and Prevention, Nanjing, Jiangsu, China

2. Tongling Center for Disease Control and Prevention, Tongling, Anhui, China

3. Chinese Field Epidemiology Training Program, Chinese Center for Disease Control and Prevention, Beijing, China

4. Tongren Center for Disease Control and Prevention, Tongren, Guizhou, China

We describe a case-control study performed in Jiangsu, China, to evaluate risk factors for human infection with novel avian influenza $\mathrm{A}\left(\mathrm{H}_{7} \mathrm{~N} 9\right)$ virus. Twenty-five cases and 93 controls matched by age, sex, and location were included in the study. Direct contact with poultry or birds in the two weeks before illness onset, chronic medical conditions (hypertension excluded), and environment-related exposures were significantly associated with $\mathrm{A}\left(\mathrm{H}_{7} \mathrm{~N} 9\right)$ infection.

Since it was discovered in February 2013, the emerging outbreak of human infections with a novel avian influenza $\mathrm{A}\left(\mathrm{H}_{7} \mathrm{~N} 9\right)$ virus in China, has raised serious concerns for public health throughout the world [1]. According to reports by China National Health and Family Planning Commission, a total of 130 confirmed cases of human infection including 37 deaths (28\%) were reported in mainland China as of 27 May 2013. Few descriptive studies have been reported on risk factors associated with avian influenza $\mathrm{A}\left(\mathrm{H}_{7} \mathrm{~N} 9\right)$ virus infection $[1,2]$. We conducted a matched case-control study to identify potential risk factors for human influenza $A\left(\mathrm{H}_{7} \mathrm{~N} 9\right)$ cases in Jiangsu Province, one of the areas where the novel reassortant influenza $A\left(\mathrm{H}_{7} \mathrm{~N}_{9}\right)$ virus emerged earliest.

\section{Selection of cases and controls}

All confirmed human cases of avian influenza $\mathrm{A}\left(\mathrm{H}_{7} \mathrm{~N}_{9}\right)$ virus infection in Jiangsu Province were included in this study. Cases were defined according to The diagnosis and treatment programs of human infections with $\mathrm{H}_{7} \mathrm{~N} 9$ virus issued by the National Health and Family Planning Commission of the People's Republic of China [3]. As of 27 May 2013, 27 confirmed cases of human infection with influenza $\mathrm{A}\left(\mathrm{H}_{7} \mathrm{~N} 9\right)$ were reported in Jiangsu; of these, eight cases were fatal.

We matched four neighbours as controls for each patient. The selection criteria included: testing negative for influenza $A\left(\mathrm{H}_{7} \mathrm{~N} 9\right)$ virus, same sex, no more than five-year age difference, and no respiratory tract symptom like cough or sore throat, or other symptoms like fever $\left(\geq 38^{\circ} \mathrm{C}\right)$ within two weeks of illness onset of the matched case. Cases were classified according to the area in which they lived: rural or urban. For cases from rural areas in the Province, controls were recruited from each patient's village according to the principle of proximity. The nearest neighbours were recruited first; if there were no eligible controls, additional controls were recruited among more distant neighbours. For cases living in urban areas, the apartment building where the patient lived was selected first. The persons in the same unit of the building were recruited first; if there were no eligible controls, the neighbours of the nearest unit were recruited next, and additional controls were recruited from the closest apartment building if needed. Investigators recruited the potential controls by visiting their homes. After the recruitment, all the eligible controls were asked to visit the local clinics for interview and blood sample collection. From each control $5 \mathrm{ml}$ venous blood was collected to exclude unapparent and/or past influenza $A\left(\mathrm{H}_{7} \mathrm{~N}_{9}\right)$ virus infection. The study was approved by the Ethics Committee of the Jiangsu Provincial Center for Disease Control and Prevention (Jiangsu CDC). Before the investigation, we obtained the informed consent of all the participants in the interview.

\section{Data collection}

We performed an epidemiological survey for all participants including demographic characteristics, health status, daily habits, and other potential risk behaviour, such as not washing hands frequently (i.e. before meals and after using toilet), smoking, etc. Interview questions were also related to the activities and environment-related exposures for both cases and controls within two weeks before the illness onset of the case. Environment-related exposure was defined as possible 


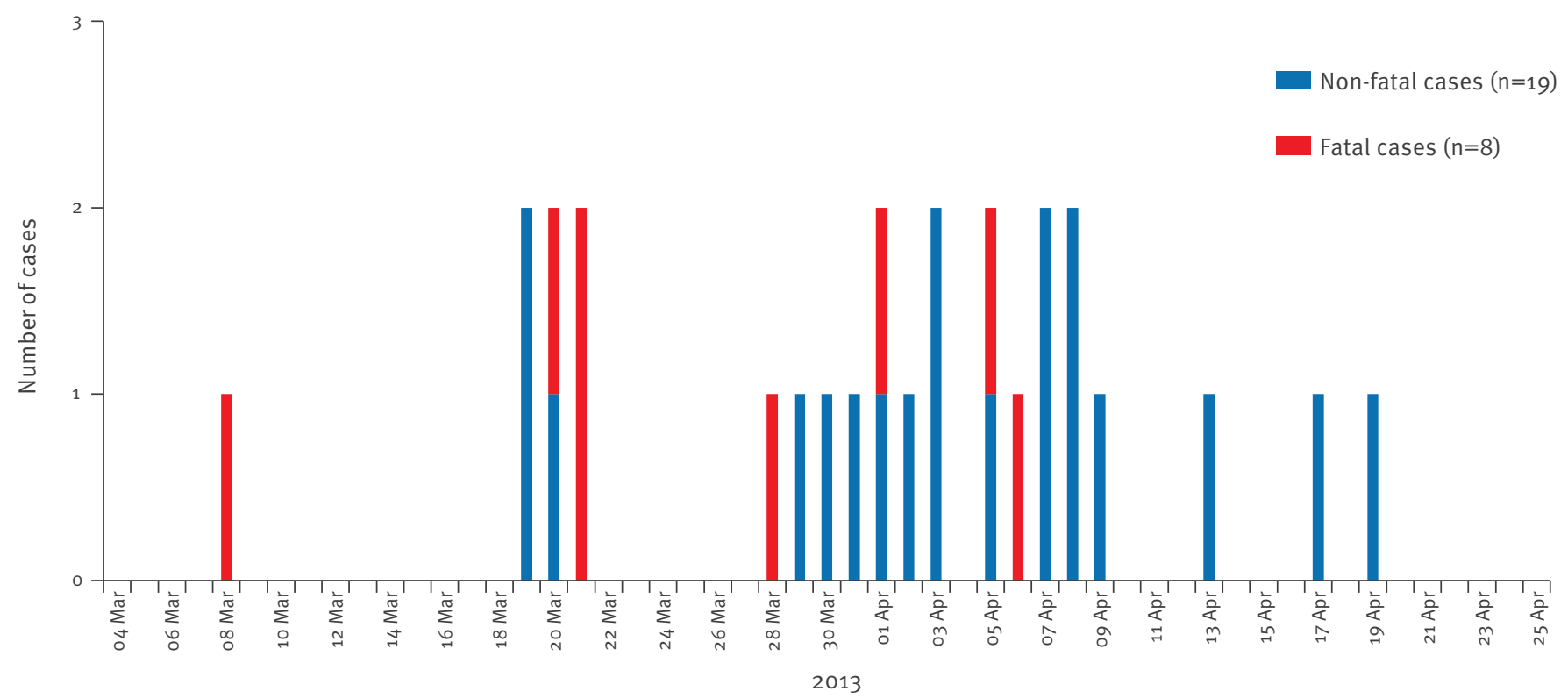

exposure due to the environment, including visiting live poultry market, bird market, buying freshly slaughtered poultry or birds in live poultry market, and chickens or pigeons raised in the neighbourhood. Direct contact included direct contact with live poultry or birds in the wet market (i.e. through culling and slaughtering), direct contact at home (i.e. through cleaning, processing or cutting), and occupational exposure. For fatal cases of influenza $A\left(\mathrm{H}_{7} \mathrm{~N} 9\right)$ infection, or for the patients too ill to participate in the interview, a family member (usually the spouse) responded to the questions for the purpose of this study. The interview was carried out by trained staff of the Jiangsu CDC and trainees of the Chinese Field Epidemiology Training Program.

\section{Laboratory investigation}

Serum samples from controls were tested by haemagglutination inhibition assay with turkey red blood cells against avian influenza $A\left(\mathrm{H}_{7} \mathrm{~N} 9\right)$ virus strain $(A /$ Jiangsu/XWQ/2013), with two confirmed patients' series serum as positive reference. All tests were performed in Jiangsu CDC.

\section{Statistical analyses}

Data were analysed using Stata/SE 9.0 for Windows (Stata Corp LP, College Station, TX, USA). Each study factor was compared between cases and controls using exact conditional logistic regression. Further multivariate conditional logistic regression was performed including all variables with $P \leq 0.10$ in univariate analyses and backward method was applied to exclude the variables with $P>0.10$.

\section{Case-control study results}

A total of 25 confirmed human influenza $\mathrm{A}\left(\mathrm{H}_{7} \mathrm{~N} 9\right)$ cases were included in the study. Two cases were excluded: one was possibly infected by human-to-human transmission (data not shown), and for the second one data were insufficient. All 25 cases included were positive in real-time PCR for influenza A virus subtype $\mathrm{H}_{7} \mathrm{~N} 9$, and 16 cases were positive in virus isolation.

The epidemiological survey was conducted from 25 April to 12 May 2013. Ninety-three controls were enrolled in this study: 22 cases had four controls matched for each, and the remaining three cases only had one, two, and two controls matched, respectively, due to unavailability of eligible controls according to the control selection criteria. All enrolled controls were seronegative for avian influenza $\mathrm{A}\left(\mathrm{H}_{7} \mathrm{~N} 9\right)$ virus antibodies. Data for 13 patients (including the eight fatal cases and the five severe cases) were obtained from family members, while data for the remaining cases and all controls were provided by themselves.

The demographic characteristics of cases and controls are showed in Table 1 . The age of the patients varied between 21 and 85 years with a median of 56 years. Twelve patients were older than 60 years and 19 were male. Twenty-two cases lived in the urban area. The characteristics of cases and controls were similar in terms of education level, family size, and family income per capita. Two patients worked in a wet poultry market (slaughtering and selling poultry) and one patient and one control worked in poultry transportation. Fifteen patients and 39 controls had chronic medical diseases, 
TABLE 1

Baseline characteristics of participants in a case-control study of avian influenza A(H7N9) in Jiangsu Province, China, 2013

\begin{tabular}{|c|c|c|c|}
\hline Characteristics & $\begin{array}{c}\text { Cases }(n=25) \\
n(\%)\end{array}$ & $\begin{array}{c}\text { Controls }(\mathrm{n}=93) \\
\mathrm{n}(\%)\end{array}$ & $p^{a}$ \\
\hline Age, median (range), years & $56(21-85)$ & $57(24-88)$ & \\
\hline$<60$ & $13(52)$ & $49(53)$ & \\
\hline$\geq 60$ & $12(48)$ & $44(47)$ & \\
\hline Male & $19(76)$ & $69(74)$ & \\
\hline \multicolumn{4}{|l|}{ Location } \\
\hline Urban area & $22(88)$ & $81(87)$ & \\
\hline Rural area & $3(12)$ & $12(13)$ & \\
\hline Interviewed by proxyb & $13(52)$ & $\mathrm{o}(0)$ & $\mathrm{NA}^{\mathrm{c}}$ \\
\hline Education level & & & 0.485 \\
\hline Primary school or below & $2(8)$ & $18(17)$ & \\
\hline Junior middle school & $13(52)$ & $30(32)$ & \\
\hline Senior middle school & $4(16)$ & $32(34)$ & \\
\hline College or higher & $6(24)$ & $13(14)$ & \\
\hline Family size, median (range), persons & $2(1-5)$ & $3(1-7)$ & 0.085 \\
\hline Family income per capita & & & 0.726 \\
\hline$\ll 2,000$ RMB (cca.250 EUR) & $7(28)$ & $23(25)$ & \\
\hline 2,000-5,000 RMB (cca. 250-625 EUR) & $14(56)$ & $53(57)$ & \\
\hline$>_{5}, 000$ RMB (cca. 625 EUR) & $4(16)$ & $17(18)$ & \\
\hline Working in wet poultry market & $2(8)$ & o (o) & $N A^{c}$ \\
\hline Working in poultry transporting & $1(4)$ & $1(1)$ & $N A^{c}$ \\
\hline Chronic medical conditions & $15(60)$ & $39(42)$ & 0.052 \\
\hline Hypertension & $10(40)$ & $31(33)$ & \\
\hline Diabetes & $4(16)$ & $7(8)$ & \\
\hline Chronic bronchitis & $3(12)$ & $3(3)$ & \\
\hline Cancer & $3(12)$ & o (o) & \\
\hline Rheumatic arthritis & $2(8)$ & $1(1)$ & \\
\hline Coronary disease & $1(4)$ & $5(5)$ & \\
\hline Other & o (o) & $6(6)$ & \\
\hline
\end{tabular}

NA: not available.

a Comparison of frequencies between cases and controls was analysed by exact conditional logistic regression; matched factors (age, sex, and location) were excluded from analyses.

b For the fatal cases or for those too ill to respond to the survey, a family member (usually the spouse) responded to the survey.

c Information not available because of small sample size or because data distribution was not suitable for conditional logistic regression model.

including hypertension, diabetes, cancer, chronic bronchitis, rheumatic arthritis, and coronary disease (Table 1).

In the univariate analysis, the following exposures were associated with a high risk of infection with influenza $A\left(\mathrm{H}_{7} \mathrm{~N} 9\right)$ : direct contact with poultry or birds within two weeks before illness onset (direct contact with poultry or birds in live poultry market, direct contact through preparing and cooking poultry or birds at home); environment-related exposures (visiting the market where live poultry was commercialised, buying freshly slaughtered poultry or birds in live poultry market). Frequent hand washing was associated with a reduced risk of getting infected with influenza $A\left(\mathrm{H}_{7} \mathrm{~N} 9\right)$ virus and this habit was reported more often by controls ( $89 \%$ ) than by cases. Body Mass Index (BMI) ( $\geq 25)$, having ever smoked, and travel history were not significantly different between cases and controls (Table 2).

Although a higher proportion of chronic medical diseases was noticed in cases than in controls, the difference was not statistically significant ( $P>0.05)$. 
TABLE 2

Univariate matched-pair analysis of risk factors for human infection with avian influenza A(H7N9) virus in Jiangsu Province, China, 2013

\begin{tabular}{|c|c|c|c|c|}
\hline Characteristics & $\begin{array}{c}\text { Cases }(n=25) \\
n(\%)\end{array}$ & $\begin{array}{l}\text { Controls }(n=93) \\
n(\%)\end{array}$ & OR $(95 \% \mathrm{Cl})$ & $p^{a}$ \\
\hline Chronic medical conditions & $15(60)$ & $39(42)$ & $3.2(1.0-10.0)$ & 0.052 \\
\hline Hypertension & $10(40)$ & $31(33)$ & $1.7(0.6-5.4)$ & 0.334 \\
\hline Chronic medical conditions (hypertension excluded) & $12(48)$ & $19(20)$ & $5.1(1.5-16.9)$ & 0.008 \\
\hline Body Mass Index (BMI) ( $\geq 25)$ & $5(20)$ & $32(34)$ & $0.4(0.1-1.3)$ & 0.147 \\
\hline Having ever smoked & $12(48)$ & $51(55)$ & $0.6(0.2-1.9)$ & 0.425 \\
\hline Frequent hand washing & $17(68)$ & $83(89)$ & $0.1(0.02-0.6)$ & 0.008 \\
\hline Direct contact with poultry or birds ${ }^{b}$ & $10(40)$ & $6(6)$ & $13.7(2.9-64.8)$ & 0.001 \\
\hline Direct contact with poultry or birds in live poultry market ${ }^{c}$ & $7(28)$ & $1(1)$ & $23.3(2.8-192.0)$ & 0.003 \\
\hline Prepared and cooked poultry or birds at home & $7(28)$ & $4(4)$ & $8.1(2.1-31.7)$ & 0.003 \\
\hline Occupational contact with poultry ${ }^{d}$ & $3(12)$ & $1(1)$ & $N A^{e}$ & \\
\hline Environment-related exposures ${ }^{f}$ & $20(80)$ & $45(48)$ & $6.9(1.9-25.2)$ & 0.003 \\
\hline Visited the market where live poultry was commercialised & $15(60)$ & $35(38)$ & $3.1(1.1-8.3)$ & 0.027 \\
\hline Frequency of visits to the market, mean $( \pm S D)$, days & $9.3 \pm 5.6$ & $6.4 \pm 5.0$ & & \\
\hline Never & $10(40)$ & $58(62)$ & Reference & \\
\hline $1-5$ times & $5(20)$ & $17(18)$ & $1.5(0.4-5.5)$ & 0.547 \\
\hline 6-10 times & $1(4)$ & $9(10)$ & $0.8(0.1-7.4)$ & 0.822 \\
\hline$>10$ times & $9(36)$ & $9(10)$ & $8.8(2.2-35.1)$ & 0.002 \\
\hline $\begin{array}{l}\text { Bought freshly slaughtered poultry or birds in live poultry } \\
\text { market }\end{array}$ & $13(52)$ & $18(19)$ & $7.3(2.3-23.8)$ & 0.001 \\
\hline Raise poultry or birds & $1(4)$ & $4(4)$ & $0.7(0.1-6.7)$ & 0.752 \\
\hline Travel history & $3(12)$ & $8(9)$ & $1.2(0.2-7.2)$ & 0.850 \\
\hline Exposed to persons with fever and respiratory symptoms & o (o) & 1 (1) & $\mathrm{NA}^{\mathrm{e}}$ & \\
\hline
\end{tabular}

$\mathrm{Cl}$ : confidence interval; NA: not available; OR: odds ratio; SD: standard deviation.

a Comparison of frequencies between patients and controls were analysed by exact conditional logistic regression.

b Birds include pigeons and quails.

Live poultry market includes poultry stall, retail or wholesale market selling live poultry and birds.

d Workplace exposure to live poultry (e.g. poultry stall, retail or wholesale market, live poultry transporting).

e Information not available because of small sample size or because data distribution was not suitable for conditional logistic regression model.

f Includes visiting live poultry market, bird market, buying freshly slaughtered poultry or birds in live poultry market and chickens or pigeons raised in neighbourhood.

$\mathrm{g}$ Travel outside home place for more than 24 hours during the two weeks prior to the patient's illness onset.

Hypertension was high in both groups, the proportion was $40 \%$ among cases and $33 \%$ among controls ( $P>0.05$ ). By excluding hypertension, $48 \%$ of cases had chronic medical diseases compared to $20 \%$ of controls, resulting an OR of 5.1 (95\% $\mathrm{Cl} 1.5-16.9 ; P=0.008)$. In the multivariate conditional logistic regression model, three variables represented significant risk factors for human influenza $\mathrm{A}\left(\mathrm{H}_{7} \mathrm{~N} 9\right)$ virus infection: direct contact with poultry or birds, chronic medical conditions (hypertension excluded) and environment-related exposures (Table 3).

\section{Discussion}

In this study, we identified in the multivariate analysis three risk factors for human influenza $A\left(\mathrm{H}_{7} \mathrm{~N}_{9}\right)$ cases in Jiangsu, China, including direct contact with poultry or birds, environment-related exposures, and chronic medical conditions (hypertension excluded). Direct contact with poultry or birds was the most significant risk factor, which is consistent with previous studies on human cases of avian influenza $\mathrm{A}\left(\mathrm{H}_{5} \mathrm{~N}_{1}\right)$ and $A\left(\mathrm{H}_{7} \mathrm{Ng}\right)$ virus infection $[2,4-8]$. The mixing of multiple 
TABLE 3

Results of multivariate analysis of risk factors for human infection with avian influenza A(H7N9) virus infection in Jiangsu Province, China, 2013

\begin{tabular}{|l|c|}
\hline Exposure and characteristics & Odds ratio (95\% confidence interval) \\
\hline Chronic medical conditions (hypertension excluded) & $6.0(1.3-27.3)$ \\
\hline Direct contact with poultry & $9.1(1.6-50.9)$ \\
\hline Environment-related exposures & $4.2(0.9-19.6)$ \\
\hline
\end{tabular}

Variables with $P<0.10$ were included in univariate matched analyses for the initial model.

a Multivariate analysis using conditional logistic regression, final model with three variables entered.

species of live poultry and birds in live poultry markets in China creates a dynamic micro-environment that favours interspecies transmission [9]. In wet poultry markets, the secretions, faeces and organs of poultry were splashed out, which made the surroundings easily contaminated and visitors more likely be exposed to infected poultry. Surveillance of live poultry markets in epidemic regions indicated that the poultry cages were positive for avian influenza $A\left(\mathrm{H}_{7} \mathrm{~N}\right.$ ) $)$ virus [10]. The univariate analysis showed that for persons who went to live poultry markets more frequently (>10 times within two weeks of illness onset) the risk of exposure to influenza $\mathrm{A}\left(\mathrm{H}_{7} \mathrm{N9}\right)$ virus was significantly higher and this could be due to the frequency of exposures. In addition, inhalation of aerosolised material contaminated with influenza $\mathrm{A}\left(\mathrm{H}_{7} \mathrm{~N} 9\right)$ viruses may be a possible transmission route; however, our study did not investigate this potential transmission vehicle.

Different from influenza $\mathrm{A}\left(\mathrm{H}_{5} \mathrm{~N}_{1}\right)$ virus infection, our findings show that having an underlying medical condition/co-morbidities (hypertension excluded) was significantly associated with influenza $A\left(\mathrm{H}_{7} \mathrm{~N} 9\right)$ virus infection. Age increases the risk for chronic diseases, which has been well-matched between cases and controls in this study. Therefore, a high proportion of elderly patients with severe influenza $A\left(\mathrm{H}_{7} \mathrm{~N} 9\right)$ virus infection may be due to decreased immune function caused by underlying chronic diseases [9].

Although influenza $\mathrm{A}\left(\mathrm{H}_{7} \mathrm{~N} 9\right)$ virus is highly pathogenic in humans, poultry infected with it do not develop any obvious or visible diseases. It is thus difficult to separate the infected poultry or birds from the un-infected ones. People, especially those with underlying diseases, such as chronic bronchitis, diabetes, cancers, rheumatic arthritis, and immunodeficiency disease, could avoid the risk by reducing exposure to possibly contaminated environment. Persons exposed to poultry are advised to undertake appropriate protection and to develop correct hand washing habits.
Our study has several potential limitations. First, the number of cases was small, limiting the power of the study to demonstrate significant associations. Second, for some cases, family members responded to the interview and it is possible that they were less likely to be aware of specific exposures and activities, and this may result in bias to the data. Third, recall bias may be included as well since participants in the study were asked about activities that had occurred one month before the survey. Fourth, as residence was one of matching factors for cases and controls in this study, this could lead to some underestimation of the risk as the neighbourhood may share some living environmental exposures with cases.

In conclusion, ongoing education of the public is needed for behavioural changes in order to decrease the exposure risk to influenza $\mathrm{A}\left(\mathrm{H}_{7} \mathrm{~N} 9\right)$ virus. Additionally, effective control strategies should be implemented; the most drastic measure would be closing the live poultry markets but if this is not possible, other measures such as segregating bird species, improving biosecurity, and having centralised poultry slaughtering locations, regular disinfection, and a periodical rest day, should be considered [11,12]. In addition, wearing protective masks or respirators by workers and visitors to wet poultry markets could be discussed.

\section{Acknowledgements}

We thank the Centers for Disease Control and Prevention of Nanjing, Suzhou, Wuxi, Zhenjiang, Changzhou, Yancheng, Yangzhou, Suqian cities in Jiangsu Province for coordinating our field investigations and collecting data. This work was supported by the Jiangsu Province Health Development Project with Science and Education (ZX201109 and RC2011085) and Chinese Field Epidemiology Training Program.

Conflict of interest

None declared. 


\section{Authors' contributions}

Jing Ai, Yong Huang, Ke Xu, Dafei Ren contributed equally to this study. Yefei Zhu, Guoqing Shi, Tao Shen, Minghao Zhou, Hua Wang designed the study. Jing Ai, Yong Huang, Ke $\mathrm{Xu}$, Dafei Ren, Hong Ji, and Qigang Dai collected, analysed and interpreted data. Xian Qi detected the specimens. Jing $\mathrm{Ai}$, Yong Huang, Ke Xu, Jingxin Li, and Yefei Zhu drafted the article. All authors reviewed and revised the first and final drafts of this manuscript.

\section{References}

1. Gao R, Cao B, Hu Y, Feng Z, Wang D, Hu W, et al. Human Infection with a Novel Avian-Origin Influenza A ( $\left.\mathrm{H}_{7} \mathrm{~N} 9\right)$ Virus. N Engl J Med. 2013;368(20):1888-97. http://dx.doi.org/10.1056/ NEJMoa1304459. PMid:23577628.

2. Chen Y, Liang W, Yang S, Wu N, Gao H, Sheng J, et al. Human infections with the emerging avian influenza $\mathrm{A} \mathrm{H}_{7} \mathrm{~N} 9$ virus from wet market poultry: clinical analysis and characterisation of viral genome. Lancet. 2013;381(9881):1916-25. http://dx.doi. org/10.1016/S0140-6736(13)60903-4

3. China National Health and Family Planning Commission. Diagnostic and treatment protocol for human infections with avian influenza $\mathrm{A}\left(\mathrm{H}_{7} \mathrm{~N} 9\right)$ (2nd edition, 2013). Beijing: China National Health and Family Planning Commission. 11 Apr 2013. Available from: http://www.moh.gov.cn/yjb/bmdt/201304/9e9 89ebaodod450oba5dbb89c3bd7829.shtml

4. Mounts AW, Kwong H, Izurieta HS, Ho Y-y, Au T-k, Lee M, et al. Case-control study of risk factors for avian influenza $A\left(\mathrm{H}_{5} \mathrm{~N}_{1}\right)$ disease, Hong Kong, 1997. J Infect Dis. 1999;180(2):505-8. http://dx.doi.org/10.1086/314903. PMid:10395870.

5. Dinh PN, Long HT, Tien NTK, Hien NT, Mai LTQ, Phong LH, et al. Risk factors for human infection with avian influenza $A$ $\mathrm{H}_{5} \mathrm{~N}_{1}$, Vietnam, 2004. Emerg Infect Dis. 2006;12(12):1841-7. http://dx.doi.org/10.3201/eid1212.060829. PMid:17326934. PMCid:3291373.

6. Areechokchai D, Jiraphongsa C, Laosiritaworn Y, Hanshaoworakul W, O'Reilly M. Investigation of avian influenza $\left(\mathrm{H}_{5} \mathrm{~N}_{1}\right)$ outbreak in humans-Thailand, 2004. MMWR Morb Mortal Wkly Rep. 2006;55(Suppl 1):3-6. PMid:16645574.

7. Zhou L, Liao Q, Dong L, Huai Y, Bai T, Xiang N, et al. Risk factors for human illness with avian influenza $A\left(\mathrm{H}_{5} \mathrm{~N}_{1}\right)$ virus infection in China. J Infect Dis. 2009;199(12):1726-34. http:// dx.doi.org/10.1086/599206. PMid:19416076. PMCid:2759027.

8. Li Q, Zhou L, Zhou M, Chen Z, Li F, Wu H, et al. Preliminary Report: Epidemiology of the Avian Influenza A (H7N9) Outbreak in China. N Engl J Med. 2013 Apr 24. [Epub ahead of print]. http://dx.doi.org/10.1056/NEJMoa1304617

9. Guan Y, Farooqui A, Zhu H, Dong W, Wang J, Kelvin DJ. H7N9 Incident, immune status, the elderly and a warning of an influenza pandemic. J Infect Dev Ctries. 2013;7(4):302-7. http:// dx.doi.org/10.3855/jidc.3675. PMid:23592638.

10. Bao CJ, Cui LB, Zhou MH, Hong L, Gao GF, Wang H. LiveAnimal Markets and Influenza A ( $\left.\mathrm{H}_{7} \mathrm{~N} 9\right)$ Virus Infection. N Engl J Med. 2013;368(24):2337-9. http://dx.doi.org/10.1056/ NEJMC1306100. PMid:23697471.

11. Kung N, Guan Y, Perkins N, Bissett L, Ellis T, Sims L, et al. The impact of a monthly rest day on avian influenza virus isolation rates in retail live poultry markets in Hong Kong. Avian Dis. 2003;47(3 Suppl):1037-41. http://dx.doi.org/10.1637/00052086-47.S3.1037. PMid:14575106.

12. Ellis TM, Barry Bousfield R, Bissett LA, Dyrting KC, Luk GS, Tsim S, et al. Investigation of outbreaks of highly pathogenic $\mathrm{H}_{5} \mathrm{~N} 1$ avian influenza in waterfowl and wild birds in Hong Kong in late 2002. Avian Pathol. 2004;33(5):492-505. http://dx.doi. org/10.1080/03079450400003601. PMid:15545029. 